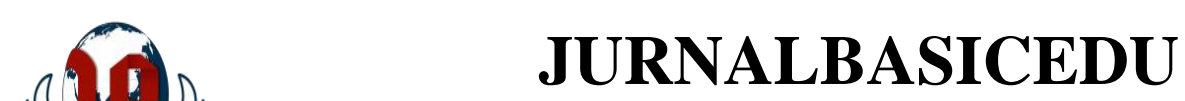

Volume 5 Nomor 5Tahun 2021 Halaman 3167 - 3178

Research \&Learningin Elementary Education

https://jbasic.org/index.php/basicedu

PAHLAWAN

\title{
Pengaruh Penggunaan Reward Stiker Pictured terhadap Kemampuan Membaca Puisi Siswa di Sekolah Dasar
}

\author{
Khafita Wahdatul Khoiroh ${ }^{1 凶}$, Syamsul Ghufron ${ }^{2}$, Nafiah ${ }^{3}$, Sri Hartatik \\ Universitas Nahdlatul Ulama Surabaya, Indonesia ${ }^{1,2,3,4}$ \\ E-mail: khafitawahdatul@gmail.com ${ }^{1}$, syamsyulghufron@ unusa.ac.id ${ }^{2}$, nefi_23@unusa.ac.id ${ }^{3}$,

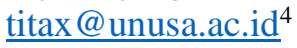

\begin{abstract}
Abstrak
Penelitian ini dilatar belakangi oleh kemampuan siswa dalam membaca puisi masih rendah, karena sebagian besar siswa kurang minat dan bakat serta motivasi yang ada pada dirinya. Adapun tujuan penelitian ini yaitu: pertama, untuk mengetahui kemampuan membaca puisi siswa sebelum menggunakan media reward stiker pictured di kelas II SD Negeri Tambak Menjangan I Lamongan. Kedua, untuk mengetahui kemampuan membaca puisi siswa sesudah menggunakan media reward stiker pictured di kelas II SD Negeri Tambak Menjangan I Lamongan. Ketiga, untuk mengetahui ada atau tidaknya pengaruh reward stiker pictured terhadap kemampuan membaca puisi siswa kelas II SD Negeri Tambak Menjangan I Lamongan. Jenis penelitian ini adalah kuantitatif dengan metode One-Group Pretest-Posttest Design. Teknik pengambilan sampel menggunakan sampel jenuh, dimana jumlah populasi juga merupakan jumlah sampel pada penelitian. Teknik pengumpulan data,penulis menggunakan pre-test dan post-test berupa hasil pengujian soal pre-test dan post-test. Teknik analisis yang digunakan adalah uji paired sample t-test. Uji prasyaratan analisis berupa uji normalitas dan homogenitas. Teknik analisis dan uji prasyaratan analisis menggunakan program komputer SPSS versi 25 . Data penelitian ini adalah hasil tes kemampuan membaca puisi sebelum dan sesudah menggunakan media reward stiker pictured. Berdasarkan hasil penelitian, H1 diterima dan H0 ditolak. Dengan demikian, media reward stiker pictured berpengaruh digunakan dalam pembelajaran puisi.
\end{abstract}

Kata Kunci: Media Reward Stiker Pictured, Kemampuan Membaca Puisi, Siswa Kelas II.

\begin{abstract}
This research is motivated the ability of students to read poetry is still low, because most students lack interest and talent in themselves. The objectives of this study are: first, to determine the students' poetry reading skills before using pictured sticker reward media in class II SD Negeri Tambak Menjangan I Lamongan. Second, to determine students' poetry reading skills after using pictured sticker reward media in class II SD Negeri Tambak Menjangan I Lamongan. Third, to determine whether or not there is an effect of pictured sticker reward on the poetry reading ability of second grade students at SD Negeri Tambak Menjangan I Lamongan. This type of research is quantitative with the One-Group PretestPosttest Design method. Data collection techniques, the authors use pre-test and post-test in the form of test results of pre-test and post-test. The analytical technique used is the paired sample t-test. The analysis prerequisite test is in the form of normality and homogeneity tests. The analysis technique and the analysis prerequisite test used the SPSS version 25 computer program.The data of this research is the result of poetry reading ability test before and after using Pictured Sticker Reward media. Based on the results of the study. HI is accepted and HO is rejected. Thus, the influential Pictured Sticker Reward media is used in poetry learning.
\end{abstract}

Keywords: Pictured Sticker Reward Media, Poetry Reading Ability, Grade II Student.

Copyright (c) 2021 Khafita Wahdatul Khoiroh, Syamsul Ghufron, Nafiah, Sri Hartatik

$\triangle$ Corresponding author :

Email : khafitawahdatul@gmail.com

DOI : https://doi.org/10.31004/basicedu.v5i5.1324

ISSN 2580-3735 (Media Cetak)

ISSN 2580-1147 (Media Online) 
3168 Pengaruh Penggunaan Reward Stiker Pictured terhadap Kemampuan Membaca Puisi Siswa di Sekolah Dasar - Khafita Wahdatul Khoiroh, Syamsul Ghufron, Nafiah, Sri Hartatik

DOI: https://doi.org/10.31004/basicedu.v5i5.1324

\section{PENDAHULUAN}

Bahasa Indonesia merupakan mata pelajaran yang bertujuan untuk mendidik siswa agar memiliki keterampilan berbahasa yang baik. Siswa dianggap memiliki kemampuan berbahasa yang baik apabila siswa dapat menuangkan ide maupun gagasannya secara lisan dan tertulis. Selain itu,melalui pembelajaran bahasa Indonesia diajarkan bagaimana cara berkomunikasi yang efektif dan efisien sesuai dengan etika dan aturan yangberlaku di masyarakat(Indriamukti, 2018:3). Mengingat pentingnya tujuan pembelajaran bahasa Indonesia tersebut dengan demikian perlu diajarkan pada anak sejak usia dini.

Pembelajaran bahasa Indonesia mempunyai empat keterampilan berbahasa yang harus dikuasai oleh siswa yaitu: menyimak, berbicara, membaca, dan menulis (Sarwiji, 2008:2). Keempat keterampilan berbahasa tersebut memiliki hubungan yang erat satu dengan yang lain. MenurutTarigan (2008:1), keterampilan berbahasadi sekolah dasar dipelajari secara sistematis sesuai dengan tahap perkembangan kemampuan berpikir siswa, mulai dari keterampilan menyimak, berbicara, membaca, dan menulis.

Peningkatan kemampuan berkomunikasi siswa dapat dilakukan dengan mengajarkan keterampilan berbahasa, salah satunya adalah keterampilan membaca. Membaca merupakan salah satu bentuk komunikasi secara langsung. Dengan membaca orang akan berusaha memahami isi yang tekandung dalam sebuah teks bacaan yang dibacanya. Salah satu keterampilan membaca di sekolah dasar adalah memahami wacana sastra melalui kegiatan membaca puisi maupun buku cerita anak. Menurut Wiranty (2017:285), membaca puisi merupakan salah satu bentuk apresiasi pada sebuah karya sastra karena pada hakikatnya pembelajaran bahasa Indonesia mengarahkan pada kepekaan perasaan siswa.

Pembelajaran bahasa Indonesia khususnya pembelajaran membaca puisi di SD Negeri Tambak Menjangan I Lamongan belum mendapatkan hasil yang optimal dalam pelaksanaan pembelajarannya. Masalah yang dihadapi adalah pengalaman guru dalam pembelajaran masih banyak yang harus dievaluasi dan perlu diadakan penelitian sehingga dapat meningkatkan kemampuan membaca puisi siswa dan hasil studi yang diperoleh siswa khususnya di kelas II.

Karena itu, dalam kurikulum 2013 jenjang SD kelas II terdapat kompetensi dasar yang berbunyi "membacakan teks puisi anak tentang alam dan lingkungan dalam bahasa Indonesia dengan lafal, intonasi dan ekspresi yang tepat sebagai bentuk ungkap diri (4.5)". Tujuannya agar siswa mampu membaca puisi indah dengan memperhatikan lafal, intonasi, dan ekspresi yang diungkapkan dengan tepat. Dengan demikian sesuai dengan tujuan tersebut seluruh siswa mampu membaca puisi dengan indah.

Kemampuan membaca puisi anak ditentukan oleh beberapa faktor yang ada pada saat pembelajaran berlangsung dan faktor dari dalam siswa. Salah satu faktor yang ada pada saat pembelajaran adalah pendekatan pembelajaran yang digunakan meliputi teknik dan strategi pembelajaran yang digunakan. Oleh karena itu, peranan guru dalam proses pembelajaran sangat penting jika dilihat dari hasil studi siswa, bahwa pembelajaran bahasa Indonesia perlu adanya perubahan dalam meningkatkan keterampilan membaca khususnya membaca puisi, baik dari guru maupun siswa sehingga kualitas pembelajaran menjadi lebih baik.

Dengan adanya masalah yang sudah diuraikan tersebut, guru harus menindaklanjuti dengan cara mencari dan mengembangkan strategi, metode maupun media yang akan digunakan untuk pembelajaran bahasa Indonesia khususnya dalam pembelajaran puisi, agar siswa dapat berpotensi meningkatkan bakat, minat, serta motivasi dan hasil belajar mereka. Guru dapat merancang pembelajaran yang aktif, inovatif, kreatif, dan menyenangkan dalam pembelajaran. Dengan menggunakan metode atau model pembelajaran yang tepat atau media pembelajaran yang relevan dengan materi bahasa Indonesia yang akan diajarkan serta menggunakan pendekatan pembelajaran yang tepat.

Berdasarkan pengalaman yang dialami oleh guru, untuk memecahkan permasalahan pembelajaran tersebut perlu adanya tindakan nyata oleh guru untuk mewujudkan hal tersebut dalam proses pembelajaran di kelas. Tindakan kelas yang dimaksud berupa upaya meningkatkan pembelajaran yang tepat dengan kondisi 
3169 Pengaruh Penggunaan Reward Stiker Pictured terhadap Kemampuan Membaca Puisi Siswa di Sekolah Dasar - Khafita Wahdatul Khoiroh, Syamsul Ghufron, Nafiah, Sri Hartatik

DOI: https://doi.org/10.31004/basicedu.v5i5.1324

dan kebutuhan gaya belajar siswa, pendekatan yang dimaksud adalah dengan penggunaan media reward stiker pictured.

Dipilihnya media reward stiker pictured adalah karena media reward memiliki keunggulan. Menurut Severe (2003:170), stiker dapat memberikan umpan balik positif terhadap prestasi belajar siswa sehingga stiker menciptakan rasa keberhasilan dan motivasi internal yang dapat mengembangkan rasa percaya diri dalam siswa. Kita dapat melihat semangat dalam mata mereka ketika mendapatkan stiker dengan gambar muka-muka yang lucu.

Selain itu, media ini telah terbukti dapat meningkatkan kepercayaan diri siswa, disiplin belajar siswa, dan kecerdasan interpersonal siswa berdasarkan hasil penelitian Rahayu (2012),Khodijah (2015), dan Agustina (2020). Namun,di antara penelitian tersebut belum ada yang menggunakan variabel kemampuan membaca puisi sebagai variabel penelitiannya.

Berdasarkan pemikiran tersebut, peneliti sangat tertarik melakukan penelitian tentang penggunaan reward stiker pictured dalam pembelajaran membaca puisi. Oleh karena itu, peneliti memilih judul "Pengaruh Penggunaan Reward Stiker Pictured terhadap Kemampuan Membaca Puisi Siswa Kelas II SD NegeriTambak Menjangan I Lamongan".

\section{METODE PENELITIAN}

Penelitian ini menggunakan pendekatan kuantitatif dengan metode eksperimen. Sugiyono (2015:107) menyatakan bahwa metode penelitian eksperimen merupakan metode penelitian yang digunakan untuk mencari pengaruh perlakuan tertentu terhadap yang lain dalam kondisi yang terkendali. Desain eksperimen yang digunakan dalam penelitian ini adalah Pre Experimental Design. Desain eksperimen ini menggunakan satu sample penelitian. Bentuk desain penelitian dari Pre Experimental Design adalah dengan model One Group Pre-test Post-test. Desain ini, menggunakan satu sample yang akan diberikan Pretest untuk mengetahui hasil sebelum diberikan perlakuan dan post-test. Dalam penelitian ini teknik pengumpulan data yang digunakan oleh peneliti adalah tes. Tes digunakan untuk mengukur keterampilan, pengetahuan, intelegensi, kemampuan atau bakat yang dimiliki oleh individu atau kelompok(Adi, 2017:44). Teknik analisis data pada penelitian ini adalah uji validitas soal dan perangkat pembelajaran.

\section{HASIL DAN PEMBAHASAN}

\section{Hasil Uji Validasi Ahli dan Uji Reabilitas Instrumen Penelitian}

Pada penelitian dengan judul "Pengaruh Penggunaan Reward Stiker Pictured terhadap Kemampuan Membaca Puisi Siswa Kelas II SD Negeri Tambak Menjangan 1 Lamongan”, sebelum soal-soal pre-test dan post-test disebar pada objek sesungguhnya terlebih dahulu perlu divalidasi oleh ahli. Untuk mengukur kevalidan suatu instrumen RPP dan soal-soal tes pengetahuan dapat dilakukan dengan cara korelasi antar skor variabel. Uji signifikansi dapat dilakukan dengan membandingkan nilai $\mathrm{r}$ hitung dengan $\mathrm{r}$ table untuk degree of freedom $(\mathrm{df})=\mathrm{n}-2$ (Ghozali, 2011). Pada penelitian ini menggunakan responden sebanyak 16 siswa, maka dapat dilihat pada tabel kritik nilai $r$ baris ke-14 (16-2) untuk taraf signifikansi 5\% yaitu 0,4973. Kevalidan data dapat diketahui jika $r$ hitung bernilai positif dan lebih besar dibandingkan dengan nilai $r$ tabel.

a. Hasil Validasi Ahli

Validasi ahli dilakukan untuk menguji perangkat pembelajaran RPP dan tes puisi. Hasil uji validitas RPP dan tes kemampuan membaca puisi siswa yang dilakukan oleh validator ahli adalah sebagai berikut. 
3170 Pengaruh Penggunaan Reward Stiker Pictured terhadap Kemampuan Membaca Puisi Siswa di Sekolah Dasar - Khafita Wahdatul Khoiroh, Syamsul Ghufron, Nafiah, Sri Hartatik

DOI: https://doi.org/10.31004/basicedu.v5i5.1324

\section{Tabel 1 Hasil Validasi Perangkat Pembelajaran RPP}

\begin{tabular}{|c|c|c|c|c|}
\hline \multirow{2}{*}{ No } & \multirow{2}{*}{ Aspek yang Dinilai } & \multicolumn{3}{|c|}{$\begin{array}{l}\text { Skala penilaian } \\
\end{array}$} \\
\hline & & Validator 1 & Validator2 & Rata-rata \\
\hline \multirow[t]{2}{*}{1.} & Identitas Mata Pelajaran & & & \\
\hline & $\begin{array}{l}\text { a. Terdapat satuan pendidikan, kelas, } \\
\text { semester, materi, alokasi waktu }\end{array}$ & 4 & 4 & 4 \\
\hline \multirow[t]{4}{*}{2.} & Pertemuan Indikator & & & \\
\hline & $\begin{array}{l}\text { a. Rumusan indikator dijabarkan dari KD, } \\
\text { sesuai, dan mewakili kompetensi dasar }\end{array}$ & 4 & 4 & 4 \\
\hline & $\begin{array}{l}\text { b. Rumusan indikator ditulis dengan rumusan } \\
\text { terdiri atas kata kerja operasional (KKO) } \\
\text { dan materi pelajaran. Kata kerja } \\
\text { operasional terukur, dapat diamati }\end{array}$ & 4 & 4 & 4 \\
\hline & $\begin{array}{l}\text { c. Rumusan indikator sesuai dengan rumusan } \\
\text { indikator pengetahuan, atau keterampilan } \\
\text { atau sikap }\end{array}$ & 4 & 4 & 4 \\
\hline
\end{tabular}

3. Perumusan TujuanPembelajaran

a. Rumusan tujuan berasal dari rumusan indikator yang telah dilengkapi dengan komponen A, B, C, dan $\mathrm{D}$ (Audience, Behaviour, Condition, dan Degree)

\begin{tabular}{lllll}
\hline b. $\begin{array}{l}\text { Kondisi di dalam pembelajaran } \\
\text { menggunakan kondisi pembelajaran atau } \\
\text { penilaian (salah satu) }\end{array}$ & 4 & 4 & 4 \\
c. $\begin{array}{l}\text { Degree yang digunakan di dalam rumusan } \\
\text { tujuan dapat diukur, dapat diamati dan } \\
\text { mudah diditentukan ketercapaiannya }\end{array}$ & 3 & 3 & 3 \\
\hline
\end{tabular}

4. Pemilihan Materi Pelajaran

\begin{tabular}{lllll} 
a. & $\begin{array}{l}\text { Materi Pelajaran sesuai dengan materi yang } \\
\text { terdapat di dalam Indikator atau tujuan }\end{array}$ & 4 & 4 & 4 \\
\hline b. & Keluasan dan kedalaman materi pelajaran & 4 & 4 & 4
\end{tabular}

b. Keluasan dan kedalaman materi pelajaran $4 \quad 44$ sesuai dengan karakteristik peserta didik/tingkat perkembangan peserta didik

d. Materi pelajaran disusun secara runtut, sistematik mulai dari kongkrit ke abstrak, dari mudah ke yang sulit

5. Pemilihan Sumber Belajar

\begin{tabular}{lllll}
\hline a. & $\begin{array}{l}\text { Sumber belajar yang dipilih sangat sesuai } \\
\text { dengan tujuan pembelajaran }\end{array}$ & 3 & 3 & 3 \\
\hline b. & $\begin{array}{l}\text { Sumber belajar yang dipilih sangat cocok } \\
\text { dengan tingkat perkembangan dan } \\
\text { karakteristik peserta didik }\end{array}$ & 4 & 4 & 4 \\
\hline c. & Sumber belajar terdapat di xsekitar peserta & 4 & 4 & 4
\end{tabular}
didik, mudah diperoleh, dan mudah diakses

6. Pemilihan Model Pembelajaran

\begin{tabular}{lllll}
\hline a. & $\begin{array}{l}\text { Model pembelajaran yang dipilih sesuai } \\
\text { dengan tujuan pembelajaran }\end{array}$ & 3 & 3 & 3 \\
\hline b. & $\begin{array}{l}\text { Langkah-langkah model pembelajaran } \\
\text { secara eksplisit tercermin di dalam } \\
\text { langkah-langkah pembelajaran yang }\end{array}$ & 3 & 3 & 3 \\
\hline
\end{tabular}


3171 Pengaruh Penggunaan Reward Stiker Pictured terhadap Kemampuan Membaca Puisi Siswa di Sekolah Dasar - Khafita Wahdatul Khoiroh, Syamsul Ghufron, Nafiah, Sri Hartatik

DOI: https://doi.org/10.31004/basicedu.v5i5.1324

\begin{tabular}{|c|c|c|c|c|}
\hline \multirow{4}{*}{ No } & \multirow{2}{*}{ Aspek yang Dinilai } & \multicolumn{3}{|c|}{$\begin{array}{c}\text { Skala penilaian } \\
\end{array}$} \\
\hline & & Validator 1 & Validator2 & Rata-rata \\
\hline & dirumuskan di dalam RPP & & & \\
\hline & $\begin{array}{l}\text { c. Model pembelajaran yang dipilih sangat } \\
\text { sesuai dengan karakteristik khususnya } \\
\text { tingkat perkembangan peserta didik }\end{array}$ & 3 & 3 & 3 \\
\hline \multirow[t]{3}{*}{7.} & \multicolumn{4}{|l|}{ Metode Pembelajaran } \\
\hline & $\begin{array}{l}\text { Metode pembelajaran yang dipilih sangat } \\
\text { sesuai dengan dengan tujuan pembelajaran }\end{array}$ & 4 & 4 & 4 \\
\hline & $\begin{array}{l}\text { b. Metode Pembelajaran yang dipilih sangat } \\
\text { sesuai dengan karakteristik peserta didik }\end{array}$ & 4 & 4 & 4 \\
\hline \multirow[t]{9}{*}{8.} & \multicolumn{4}{|l|}{ Skenario Pembelajaran } \\
\hline & $\begin{array}{l}\text { a. Menampilkan kegiatan pendahuluan, inti, } \\
\text { dan penutup dengan jelas }\end{array}$ & 4 & 4 & 4 \\
\hline & $\begin{array}{l}\text { b. Pada kegiatan ini setidaknya dirancang } \\
\text { kegiatan motivasi, apersepsi, dan } \\
\text { menunculkan masalah yang akan } \\
\text { diselesaikan baik secara sendiri-sendiri } \\
\text { maupun terintegrasi misalnya dalam bentuk } \\
\text { cerita, lagu, atau video tentang suatu } \\
\text { fenomena }\end{array}$ & 4 & 4 & 4 \\
\hline & $\begin{array}{l}\text { c. Pada kegiatan inti setidaknya terdapat } \\
\text { aktivitas berpusat pada siswa (membaca, } \\
\text { diskusi, pengamatan atau eksperimen) } \\
\text { untuk menemukan informasi atau jawaban } \\
\text { terhadap masalah yang muncukl di } \\
\text { kegiatan awal dan ada penyimpulan pada } \\
\text { akhir kegiatan inti }\end{array}$ & 4 & 4 & 4 \\
\hline & $\begin{array}{l}\text { d. Pada kegiatan penutup berfungsi menguat } \\
\text { retensi (ingatan) peserta didik, dilakukan } \\
\text { setidaknya berupa evaluasi atau membuat } \\
\text { rangkuman, atau mencari bentuk penerapan } \\
\text { hal-hal yang sudah dipelajari dalam } \\
\text { kegiatan inti }\end{array}$ & 4 & 4 & 4 \\
\hline & $\begin{array}{ll}\text { e. Langkah-langkah pembelajaran tampak } \\
\text { sesuai dengan model pembelajaran }\end{array}$ & 3 & 3 & 3 \\
\hline & $\begin{array}{l}\text { c. Ciri spesifik metode pembelajaran tampak } \\
\text { di dalam Langkah-langkah pembelajaran }\end{array}$ & 3 & 3 & 3 \\
\hline & $\begin{array}{l}\text { d. Materi disajikan dengan cara yang sesuai } \\
\text { dengan model dan metodepembelajaran } \\
\text { dilakukan secara sistematik, runtut dari } \\
\text { yang mudah yang ke yang sukar dan dari } \\
\text { yang kongkrit ke yang abstrak, dari yang } \\
\text { dekat dengan peserta didik (kontekstual) ke } \\
\text { yang jauh }\end{array}$ & 4 & 4 & 4 \\
\hline & $\begin{array}{l}\text { e. Alokasi waktu yang disediakan sesuai } \\
\begin{array}{l}\text { dengan aktivitas pembelajaran yang } \\
\text { dirancang }\end{array}\end{array}$ & 4 & 4 & 4 \\
\hline \multirow[t]{2}{*}{9.} & \multicolumn{4}{|l|}{ Rancangan Penilaian Autentik } \\
\hline & $\begin{array}{l}\text { a. Kesesuaian bentuk, teknik, dan instrumen } \\
\text { dengan indikator pencapaian kompetensi } \\
\text { (kesesuaian antara tagihan dalam tujuan }\end{array}$ & 3 & 3 & 3 \\
\hline
\end{tabular}


3172 Pengaruh Penggunaan Reward Stiker Pictured terhadap Kemampuan Membaca Puisi Siswa di Sekolah Dasar - Khafita Wahdatul Khoiroh, Syamsul Ghufron, Nafiah, Sri Hartatik

DOI: https://doi.org/10.31004/basicedu.v5i5.1324

\begin{tabular}{llccc}
\hline \multirow{2}{*}{ No } & \multicolumn{1}{c}{ Aspek yang Dinilai } & \multicolumn{3}{c}{ Skala penilaian } \\
\cline { 2 - 5 } & $\begin{array}{l}\text { Vaitu kata kerja operasional dengan strategi } \\
\text { dan bentuk instrument alat ukur) }\end{array}$ & & & \\
\cline { 2 - 5 } & $\begin{array}{l}\text { Instrumen penilaian meliputi semua tujuan } \\
\text { yang telah dirumuskan (pengetahuan, } \\
\text { keterampilan, sikap) sesuai dengan } \\
\text { rumusan yang ada di tujuan }\end{array}$ & & & \\
\hline & Rata-rata & $\mathbf{3 , 6 7}$ & $\mathbf{3 , 7 1}$ & $\mathbf{3 , 6 9}$ \\
\hline
\end{tabular}

Sumber: Data Penelitian

Dari tabel 1 diketahui bahwa nilai rata-rata dari validator 1 sebesar 3,67 dengan catatan ada sedikit revisi. Nilai rata-rata dari validator 2 sebesar 3,71 dengan catatan ada sedikit revisi. Dari kedua nilai ratarata yang diperoleh nilai rata-rata secara keseluruhan yaitu 3,69 sehingga kesimpulan dari perangkat pemeblajaran RPP layak digunakan dengan sedikit revisi. Instrumen ini telah direvisi sesuai saran dari validator, sehingga layak digunakan. Hasil uji validitas berikutnya adalah uji validitas untuk tes kemampuan membaca puisi yang dilakukan oleh validator ahli adalah sebagai berikut.

Tabel 2 Hasil Validasi Tes Puisi (Pretest dan Posttest)

\begin{tabular}{|c|c|c|c|c|}
\hline No & Aspek Penilaian & & Penilaian & \\
\hline I. & Kriteria Isi Materi & Validator 1 & Validator 2 & Rata-rata \\
\hline 1. & Sesuai dengan indikator & 4 & 4 & 4 \\
\hline 2. & $\begin{array}{l}\text { Susunan kalimat tidak menimbulkan penafsiran } \\
\text { ganda }\end{array}$ & 3 & 3 & 3 \\
\hline 3. & $\begin{array}{l}\text { Rumusan masalah menggunakan kalimat } \\
\text { Tanya atau perintah yang meminta jawaban } \\
\text { uraian }\end{array}$ & 3 & 3 & 3 \\
\hline 4. & $\begin{array}{l}\text { Materi yang ditanyakan sesuai dengan } \\
\text { kompetensi yang akan diukur }\end{array}$ & 3 & 4 & 3,5 \\
\hline 5. & Menggunakan masalah kontekstual & 3 & 3 & 3 \\
\hline II. & Kriteria Bahasa & & & \\
\hline 1. & $\begin{array}{l}\text { Menggunakan bahasa yang sesuai dengan } \\
\text { kaidah EYD (Ejaan Yang Disempurnakan) }\end{array}$ & 2 & 3 & 2,5 \\
\hline 2. & Menggunakan bahasa yang komunikatif & 3 & 3 & 3 \\
\hline 3. & $\begin{array}{l}\text { Rumusan masalah menggunakan kata-kata } \\
\text { yang dikenal dan mudah dipahami siswa }\end{array}$ & 3 & 3 & 3 \\
\hline 4. & $\begin{array}{l}\text { Rumusan Masalah tidak menimbulkan } \\
\text { penafsiran Ganda }\end{array}$ & 3 & 3 & 3 \\
\hline & Rata-rata & 3 & 3 & 3 \\
\hline
\end{tabular}

Sumber: Data Penelitian

Dari Tabel 2 diketahui bahwa nilai rata-raat dari validator 1 sebesar 3 dengan catatan ada sedikit revisi untuk memperbaiki penulisan. Nilai rata-rata dari validator 2 sebesar 3 dengan catatan ada sedikit revisi. Dari kedua nilai rata-rata diperoleh nilai rata-rata keseluruhan yaitu 3 sehingga dapat disimpulkan bahwa instrumen tes kemampuan membaca puisi dapat digunakan dengan sedikit revisi. Instrumen ini telah direvisi sesuai saran dari validator, sehingga layak digunakan. 
3173 Pengaruh Penggunaan Reward Stiker Pictured terhadap Kemampuan Membaca Puisi Siswa di Sekolah Dasar - Khafita Wahdatul Khoiroh, Syamsul Ghufron, Nafiah, Sri Hartatik

DOI: https://doi.org/10.31004/basicedu.v5i5.1324

b. Uji Reliabilitas

Uji reliabilitas pada penelitian ini menggunakan bantuan software komputer SPSS versi 25. Berikut adalah hasil uji reliabilitas instrumen penelitian ini.

Tabel 3 Hasil Uji Reliabilitas Tes Kemampuan Membaca Puisi dengan Bantuan SPSS Versi 25

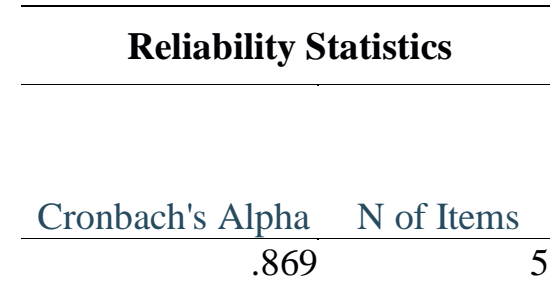

Tabel 3 diketahui bahwa pada penelitian ini memiliki kriteria reliabel karena menghasilkan nilai Alpha Cronbach sebesar 0,869 untuk penilaian tes kemampuan membaca puisi. Kesimpulan dari hasil uji reliabilitas dapat dikatakan reliabel karena memiliki nilai Alpha Cronbach $\geq 0,869$.

\section{Kemampuan Membaca Puisi Siswa Kelas II SD Negeri Tambak Menjangan 1 Lamongan Sebelum Menggunakan Reward Stiker Pictured}

Kemampuan membaca puisi siswa kelas II SD Negeri Tambak Menjangan 1 Lamongan berdasarkan data hasil pre-test yang terdiri dari 5 penilaian terhadap 16 responden siswa, dapat dikelompokkan menjadi 4 kategori penilaian. Hasil rekapitulasi kemampuan membaca puisi siswa dapat dilihat pada tabel dibawah ini.

Tabel 4 Nilai Pretest Kemampuan Membaca Puisi Sebelum Menggunakan Reward Stiker Pictured.

\begin{tabular}{|c|c|c|c|c|c|c|c|c|}
\hline \multirow[b]{2}{*}{ NO } & \multirow[b]{2}{*}{ NAMA } & \multicolumn{5}{|c|}{ Aspek yang Dinilai } & \multirow[b]{2}{*}{ Skor } & \multirow[b]{2}{*}{$\begin{array}{l}\text { Nilai } \\
\text { akhir }\end{array}$} \\
\hline & & $\begin{array}{l}\text { Lafal } \\
(1-4)\end{array}$ & $\begin{array}{c}\text { Intonasi } \\
(1-4)\end{array}$ & $\begin{array}{c}\text { Ekspresi } \\
(1-4)\end{array}$ & $\begin{array}{c}\text { Kelanc } \\
\text { aran } \\
(1-4)\end{array}$ & $\begin{array}{c}\text { Percaya } \\
\text { diri } \\
1-4)\end{array}$ & & \\
\hline 1 & $\mathrm{MF}$ & 3 & 2 & 3 & 2 & 2 & 12 & 60 \\
\hline 2 & DNS & 3 & 2 & 2 & 2 & 3 & 12 & 60 \\
\hline 3 & ANS & 3 & 3 & 2 & 2 & 3 & 13 & 65 \\
\hline 4 & $\mathrm{RIH}$ & 2 & 2 & 2 & 2 & 3 & 11 & 55 \\
\hline 5 & AQN & 3 & 3 & 3 & 3 & 4 & 16 & 80 \\
\hline 6 & AEN & 3 & 4 & 3 & 3 & 3 & 16 & 80 \\
\hline 7 & RZS & 2 & 2 & 2 & 2 & 2 & 10 & 50 \\
\hline 8 & $\mathrm{HK}$ & 2 & 2 & 2 & 2 & 2 & 10 & 50 \\
\hline 9 & $\mathrm{AMC}$ & 2 & 2 & 2 & 2 & 2 & 10 & 50 \\
\hline 10 & IM & 3 & 4 & 2 & 3 & 3 & 15 & 75 \\
\hline 11 & MV & 2 & 2 & 2 & 2 & 2 & 10 & 50 \\
\hline 12 & MA & 2 & 2 & 2 & 2 & 2 & 10 & 50 \\
\hline 13 & AAS & 2 & 2 & 2 & 2 & 2 & 10 & 50 \\
\hline 14 & AAP & 3 & 2 & 2 & 2 & 2 & 11 & 55 \\
\hline 15 & MAT & 2 & 2 & 2 & 2 & 2 & 10 & 50 \\
\hline 16 & RAA & 2 & 2 & 2 & 2 & 2 & 10 & 50 \\
\hline \multicolumn{7}{|c|}{ Rata-rata } & 11 & 58,13 \\
\hline
\end{tabular}


3174 Pengaruh Penggunaan Reward Stiker Pictured terhadap Kemampuan Membaca Puisi Siswa di Sekolah Dasar - Khafita Wahdatul Khoiroh, Syamsul Ghufron, Nafiah, Sri Hartatik

DOI: https://doi.org/10.31004/basicedu.v5i5.1324

Berdasarkan Tabel 4 di atas terlihat bahwa nilai rata-rata kemampuan membaca puisi siswa kelas II SD Negeri Tambak Menjangan 1 Lamongan adalah 58,13. Sesuai dengan kualifikasi penilaian, kemampuan membaca puisi siswa termasuk dalam kategori kurang $(<60)$.

Tabel 4 Kemampuan Membaca Puisi Siswa Sebelum Menggunakan Reward Stiker Pictured

\begin{tabular}{llllll}
\hline Penilaian & Kategori & Frekuensi (f) & Persentase (\%) & fc & fc (\%) \\
\hline $86-100$ & Baik sekali & 0 & 0 & 0 & 0 \\
\hline $71-85$ & Baik & 3 & 18,75 & 3 & 18,75 \\
\hline $60-70$ & Cukup & 3 & 18,75 & 6 & 37,5 \\
\hline$<60$ & Kurang & 10 & 62,5 & 16 & 100 \\
\hline Jumlah & & $\mathbf{1 6}$ & $\mathbf{1 0 0}$ & &
\end{tabular}

Tabel 5 di atas menunjukkan bahwa hasil dari kualifikasi penilaian kemampuan membaca puisi pada tahap pretest sebelum menggunakan Reward Stiker Pictured menunjukkan bahwa nilai 86-100 sebanyak 0 siswa dengan persentase $0 \%$, nilai 71-85 sebanyak 3 siswa dengan persentase $18,75 \%$, nilai $69-70$ sebanyak 3 siswa dengan persentase $18,75 \%$, nilai $<60$ sebanyak 10 siswa dengan persentase $62,5 \%$. Dari tabel di atas juga terlihat bahwa jumlah siswa yang mencapai nilai 71 ke atas hanya 3 siswa atau dengan persentase $18,75 \%$. Ini berarti bahwa jumlah siswa yang mendapat nilai 70 ke bawah sebanyak $81,25 \%$ (100\%-18,75\%).

\section{Kemampuan Membaca Puisi Siswa Kelas II SD Negeri Tambak Menjangan 1 Lamongan Sesudah Menggunakan Reward Stiker Pictured}

Kemampuan membaca puisi siswa kelas II SD Negeri Tambak Menjangan 1 Lamongan berdasarkan data hasil post-test yang terdiri dari 5 penilaian terhadap 16 responden siswa dapat dikelompokkan menjadi 4 kategori penilaian. Hasil rekapitulasi kemampuan membaca puisi siswa dapat dilihat pada tabel di bawah ini

Tabel 6 Nilai Posttest Kemampuan Membaca Puisi Sesudah Menggunakan Reward Stiker Pictured

\begin{tabular}{|c|c|c|c|c|c|c|c|c|}
\hline \multirow[b]{2}{*}{ NO } & \multirow[b]{2}{*}{ NAMA } & \multicolumn{5}{|c|}{ Aspek yang Dinilai } & \multirow[b]{2}{*}{ Skor } & \multirow[b]{2}{*}{$\begin{array}{l}\text { Nilai } \\
\text { akhir }\end{array}$} \\
\hline & & $\begin{array}{c}\text { Lafal } \\
(1-4)\end{array}$ & $\begin{array}{c}\text { Intonasi } \\
(1-4)\end{array}$ & $\begin{array}{c}\text { Ekspresi } \\
(1-4)\end{array}$ & $\begin{array}{c}\text { Kelancaran } \\
(1-4)\end{array}$ & $\begin{array}{c}\text { Percaya } \\
\text { diri } \\
(1-4)\end{array}$ & & \\
\hline 1 & MF & 3 & 3 & 3 & 3 & 4 & 16 & 80 \\
\hline 2 & DNS & 3 & 3 & 3 & 3 & 3 & 15 & 75 \\
\hline 3 & ANS & 3 & 3 & 3 & 3 & 4 & 16 & 80 \\
\hline 4 & RIH & 3 & 2 & 3 & 3 & 3 & 14 & 70 \\
\hline 5 & AQN & 4 & 3 & 3 & 4 & 4 & 18 & 90 \\
\hline 6 & AEN & 4 & 4 & 4 & 3 & 4 & 19 & 95 \\
\hline 7 & RZS & 3 & 3 & 3 & 3 & 3 & 15 & 75 \\
\hline 8 & $\mathrm{HK}$ & 3 & 3 & 3 & 3 & 4 & 16 & 80 \\
\hline 9 & AMC & 3 & 2 & 3 & 3 & 4 & 15 & 75 \\
\hline 10 & IM & 3 & 3 & 3 & 4 & 4 & 17 & 85 \\
\hline 11 & MV & 3 & 2 & 3 & 3 & 3 & 14 & 70 \\
\hline 12 & MA & 3 & 3 & 3 & 4 & 3 & 16 & 80 \\
\hline 13 & AAS & 3 & 3 & 3 & 3 & 3 & 15 & 75 \\
\hline
\end{tabular}


3175 Pengaruh Penggunaan Reward Stiker Pictured terhadap Kemampuan Membaca Puisi Siswa di Sekolah Dasar - Khafita Wahdatul Khoiroh, Syamsul Ghufron, Nafiah, Sri Hartatik

DOI: https://doi.org/10.31004/basicedu.v5i5.1324

\begin{tabular}{|c|c|c|c|c|c|c|c|c|}
\hline 14 & AAP & 4 & 3 & 3 & 3 & 4 & 17 & 85 \\
\hline 15 & MAT & 3 & 3 & 3 & 3 & 4 & 16 & 80 \\
\hline 16 & RAA & 3 & 2 & 3 & 3 & 3 & 14 & 70 \\
\hline
\end{tabular}

Berdasarkan Tabel 6 di atas terlihat bahwa nilai rata-rata kemampuan membaca puisi siswa kelas II SD Negeri Tambak Menjangan 1 Lamongan adalah 79,06. Sesuai dengan kualifikasi penilaian, kemampuan membaca puisi siswa termasuk dalam kategori baik $(71-85)$.

Tabel 7 Kemampuan Membaca Puisi Siswa Sesudah Menggunakan Reward Stiker Pictured

\begin{tabular}{cccccc}
\hline Penilaian & Kategori & Frekuensi (f) & Persentase (\%) & Cf & Cf (\%) \\
\hline $86-100$ & Baik sekali & 2 & 12,5 & 2 & 12,5 \\
\hline $71-85$ & Baik & 11 & 68,75 & 13 & 81,25 \\
\hline $60-70$ & Cukup & 3 & 18,75 & 16 & 100 \\
\hline$<60$ & Kurang & 0 & 0 & 16 & 100 \\
\hline & Jumlah & $\mathbf{1 6}$ & $\mathbf{1 0 0}$ & &
\end{tabular}

Tabel 7 di atas menunjukkan bahwa hasil dari kualifikasi penilaian kemampuan membaca puisi pada tahap pretest sesudah menggunakan Reward Stiker Pictured menunjukkan bahwa nilai 86-100 sebanyak 2 siswa dengan persentase $12,5 \%$, nilai $71-85$ sebanyak 11 siswa dengan persentase $68,75 \%$, nilai $69-70$ sebanyak 3 siswa dengan persentase $18,75 \%$, nilai $<60$ sebanyak 0 siswa dengan persentase $0 \%$. Dari tabel di atas juga terlihat bahwa jumlah siswa yang mencapai nilai 71 ke atas sebanyak 13 siswa atau dengan persentase $81,25 \%$.

\section{Pengaruh Penggunaan Reward Stiker Pictured Terhadap Kemampuan Membaca Puisi Siswa Kelas II SD Negeri Tambak Menjangan 1 Lamongan}

Pengaruh penggunaan reward stiker pictured terhadap kemampuan membaca puisi siswa dapat diperoleh dari uji prasyarat analisis data pearson product moment dengan menggunakan uji normalitas dan uji homogenitas. Pengujian normalitas dimaksudkan untuk membuktikan data yang didapatkan berdistribusi normal (value $\geq 0,05$ ). Uji normalitas dilakukan menggunakan uji kolmogorov smirnov dengan bantuan SPSS versi 25. Selain uji normalitas, dilakukan pula uji homogenitas dilakukan untuk mengetahui data yang diperoleh homogen atau tidak. Uji homogenitas menggunakan levens statistics dengan menggunakan SPSS Versi 25.

\section{Kemampuan Membaca Puisi Siswa Kelas II SD Negeri Tambak Menjangan 1 Lamongan Sebelum Menggunakan Reward Stiker Pictured Tergolong Kurang}

Hasil penelitian di atas menyimpulkan bahwa kemampuan membaca puisi siswa sebelum menggunakan Reward Stiker Pictured atau pretest ini masih kurang. Hal tersebut dapat dilihat dari hasil nilai rata-rata kemampuan membaca puisi siswa kelas II SD Negeri Tambak Menjangan 1 Lamongan adalah 58,13. Sesuai dengan kualifikasi penilaian, kemampuan membaca puisi siswa termasuk dalam kategori kurang $(<60)$.Proses pembelajaran sebelum menggunakan reward stiker pictured siswa terlihat kurang mampu membaca puisi dengan baik, karena pembelajaran puisi yang biasa dilakukan hanya memberikan penjelasan tanpa mempraktekkan dan kurang menekankan pada kompetensi dasar yang telah dipelajari. Sehingga ketika diadakan tes kemampuan membaca puisi terlihat dari hasil nilai rata-rata siswa masih banyak yang belum sepenuhnya memahami dan menguasai. Hal-hal yang harus diperhatikan saat membacakan sebuah puisi. Adapun pada saat kegiatan membaca puisi berlangsung kebanyakan siswa terlihat kurang percaya diri, mereka malu-malu tampil di depan teman-temannya, hal tersebut disebabkan karena mereka belum terbiasa. Selama ini metode yang digunakan pada saat pembelajaran Bahasa Indonesia yaitu teacher centered yang dimana guru menerangkan dan siswa mencatat lalu mengerjakan tugas, tanpa adanya media pembelajaran. 
3176 Pengaruh Penggunaan Reward Stiker Pictured terhadap Kemampuan Membaca Puisi Siswa di Sekolah Dasar - Khafita Wahdatul Khoiroh, Syamsul Ghufron, Nafiah, Sri Hartatik

DOI: https://doi.org/10.31004/basicedu.v5i5.1324

\section{Kemampuan Membaca Puisi Siswa Kelas II SD Negeri Tambak Menjangan 1 Lamongan Sesudah Menggunakan Reward Stiker Pictured Tergolong Baik}

Hasil penelitian di atas menyimpulkan bahwa kemampuan membaca puisi siswa sesudah menggunakan Reward Stiker Pictured atau prosttest ini tergolong baik. Hal tersebut dapat dilihat dari hasil nilai rata-rata kemampuan membaca puisi siswa kelas II SD Negeri Tambak Menjangan 1 Lamongan adalah 79,06. Sesuai dengan kualifikasi penilaian, kemampuan membaca puisi siswa termasuk dalam kategori baik (71 - 85).

Proses pembelajaran dengan menggunakan reward stiker pictured mula-mulanya diperkenalkan kepada siswa tentang reward stiker pictured yang digunakan oleh peneliti serta kegunaannya dengan langkah-langkah proses pembelajaran sebagai berikut (1) guru menjelaskan kepada siswa tentang materi puisi dan hal-hal apa saja yang harus diperhatikan pada saat membaca puisi (2) selanjutnya guru menyajikan teks puisi dan mempraktekkannya (3) kemudian siswa diminta untuk mempraktekkan membaca puisi sesuai dengan kompetensi dasar yang sudah dipelajari (4) adapun siswa yang berhasil membaca puisi dengan baik dan benar akan diberikan reward berupa stiker yang bergambar lucu dan ditempelkan pada papan prestasi sesuai dengan namanya masing-masing.

Dengan reward stiker pictured kesulitan diatas dapat diatasi, media ini menciptakan suasana pembelajaran yang lebih aktif dan menyenangkan. Sehingga teknik pembelajaran ini dapat mendorong minat belajar siswa dan dapat meningkatkan kemampuan mereka dalam membaca puisi. Hal ini sejalan dengan hasil penelitian (Ghufron \& Nafiah, 2020)yang menyatakan bahwa pembelajaran dengan pendekatan PAIKEM (Pembelajaran efektif, Inovatif, Kreatif, Efektif, dan Menyenangkan) menunjukkan hasil yang menggembirakan baik dari aktivitas guru, respon dari siswa, maupun kompetensi siswa.

\section{Ada Pengaruh Penggunaan Reward Stiker Pictured terhadap Kemampuan Membaca Puisi Siswa Kelas II SD Negeri Tambak Menjangan 1 Lamongan}

Hasil penelitian di atas menyimpulkan bahwa ada pengaruh penggunaan Reward Stiker Pictured. Hal tersebut dapat dilihat dari hasil uji paired sample t-test nilai signifikan sebesar 0,000 lebih kecil dari signifikan $0,05(0,000<0,05)$, sehingga hipotesis $\left(H_{1}\right)$ diterima. Artinya, bahwa variabel penggunaan media reward stiker pictured berpengaruh terhadap kemampuan membaca puisi siswa, ada pengaruh yang signifikan antara kemampuan membaca puisi siswa sebelum menggunakan media dengan sesudah menggunakan media reward stiker pictured siswa di kelas II SD Negeri Tambak Menjangan 1 Lamongan.

\section{KESIMPULAN}

Berdasarkan penyajian hasil penelitian dan pembahasan disimpulkan bahwa: 1) Kemampuan membaca puisi siswa sebelum menggunakan reward stiker pictured di kelas II SD Negeri Tambak Menjangan 1 Lamongan tergolong kurang. Hal ini terbukti dari nilai rata-rata 58,13. 2) Kemampuan membaca puisi siswa sesudah menggunakan reward stiker pictured di kelas II SD Negeri Tambak Menjangan 1 Lamongan tergolong baik. Hal ini terbukti dari nilai rata-rata 79,06. 3) Ada pengaruh penggunaan reward stiker pictured terhadap kemampuan membaca puisi siswa di kelas II SD Negeri Tambak Menjangan 1 Lamongan. Hal ini didasarkan pada hasil uji paired sample t-test nilai signifikan sebesar 0,000 lebih kecil dari signifikan 0,05 $(0,000<0,05)$, sehingga hipotesis $\left(H_{1}\right)$ diterima.

\section{DAFTAR PUSTAKA}

Dewi, W. A. F. (2020). Dampak Covid-19 Terhadap Implementasi Pembelajaran Daring Di Sekolah Dasar. Edukatif: Jurnal Ilmu Pendidikan, 2(1), 55-61. Https://Doi.Org/10.31004/Edukatif.V2i1.89

Fuad, Z. Al, \& Zuraini. (2016). Faktor-Faktor Yang Mempengaruhi Minat Belajar Siswa Kelas 1 Sdn 7 Kute 
3177 Pengaruh Penggunaan Reward Stiker Pictured terhadap Kemampuan Membaca Puisi Siswa di Sekolah Dasar - Khafita Wahdatul Khoiroh, Syamsul Ghufron, Nafiah, Sri Hartatik

DOI: https://doi.org/10.31004/basicedu.v5i5.1324

Panang. Jurnal Tunas Bangsa, 42-54.

Hartuti, P. M. (2015). Peran Konsep Diri, Minat Dan Kebiasaan Belajar Peserta Didik Terhadap Prestasi Belajar Fisika Purni. 5(2), 91-99.

Hermawan, I. (2019). Metodologi Penelitian Pendidikan (Kualitatif, Kuantitatif Dan Mixed Methode).Kuningan: Hidayatul Quran.

Nabila, H., \& Sulistiyaningsih, D. (2020). Analisis Kesulitan Belajar Matematika Dalam Pembelajaran Daring Berbantuan Microsoft Teams Kelas Xi Sma Negeri 9 Semarang. Edusainstech, Prosiding Seminar, Fmipa Unikus 2020, 62-71.

Nugrahani, F. (2015). Metode Penelitian Kualitatif Dalam Penelitian Pendidikan Bahasa. Yogyakarta: Nuansa Aksara.

Pratiwi, N. K. (2017). Pengaruh Tingkat Pendidikan, Perhatian Orang Tua, Dan Minat Belajar Siswa Terhadap Prestasi Belajar Bahasa Indonesia Siswa Smk Kesehatan Di Kota Tangerang. Pujangga, 1(2), 31. Https://Doi.Org/10.47313/Pujangga.V1i2.320

Putria, H., Maula, L. H., \& Uswatun, D. A. (2020). Analisis Proses Pembelajaran Dalam Jaringan (Daring) Masa Pandemi Covid- 19 Pada Guru Sekolah Dasar. Jurnal Basicedu, 4(4), 861-870. Https://Doi.Org/10.31004/Basicedu.V4i4.460

Rahmawati, N. R., Rosida, F. E., \& Kholidin, F. I. (2020). Analisis Pembelajaran Daring Saat Pandemi Di Madrasah Ibtidaiyah. Sittah: Journal of Primary Education, 1(2), 139-148. Https://Doi.Org/10.30762/Sittah.V1i2.2487

Rigianti, H. A. (2020). Kendala Pembelajaran Daring Guru Sekolah Dasar Di Kabupaten Banjarnegara. Journal Of Chemical Information And Modeling, 43(1), 7728. Https://Online210.Psych.Wisc.Edu/WpContent/Uploads/Psy-210_Unit_Materials/Psy-

210_Unit01_Materials/Frost_Blog_2020.Pdf\%0ahttps://Www.Economist.Com/Special-

Report/2020/02/06/China-Is-Making-Substantial-Investment-In-Ports-And-PipelinesWorldwide\%0ahttp://Www.

Saptoyo. (2021). Gejala Covid-19 Yang Perlu Diwaspadai. Kompas.Com. Https://Amp.Kompas.Com/Tren/Read/2021/01/26/133000565/-15-Gejala-Covid-19-Yang-PerluDiwaspadai

Siagian, M. D. (2012). Kemampuan Koneksi Matematik Dalam Pembelajaran Matematika. Unnes Journal Of Mathematics Education Research, 1(2), 58-67.

Sirait, E. D. (2016). Pengaruh Minat Belajar Terhadap Prestasi Belajar Matematika. Formatif: Jurnal Ilmiah Pendidikan Mipa, 6(1), 35-43. Https://Doi.Org/10.30998/Formatif.V6i1.750

Sobron, A. ., Bayu, Rani, \& S, M. (2019). Pengaruh Daring Learning Terhadap Hasil Belajar Ipa Siswa Sekolah Dasar Abstrak. Seminar Nasional Sains \& Entrepreneurship, 1(1), 1-5. Http://Conference.Upgris.Ac.Id/Index.Php/Snse/Article/View/204/136

Sulastri, A. (2016). Penerapan Pendekatan Kontekstual Dalam Pembelajaran Matematika Untuk Meningkatkan Pemahaman Konsep Matematis Siswa Sekolah Dasar. Jurnal Pendidikan Guru Sekolah Dasar, 1(1), 156-170. Https://Doi.Org/10.17509/Jpgsd.V1i1.9068

Susanto, A. (2016). Teori Belajar Dan Pembelajaran.Jakarta: Prenadamedia Group.

Syarifudin, A. S. (2020). Impelementasi Pembelajaran Daring Untuk Meningkatkan Mutu Pendidikan Sebagai Dampak Diterapkannya Social Distancing. Jurnal Pendidikan Bahasa Dan Sastra Indonesia Metalingua, 5(1), 31-34. Https://Doi.Org/10.21107/Metalingua.V5i1.7072

Utami, Y. P., \& Cahyono, D. A. D. (2020). Study At Home: Analisis Kesulitan Belajar Matematika Pada Proses Pembelajaran Daring. Jurnal Ilmiah Matematika Realistik, 1(1), 20-26. Https://Doi.Org/10.33365/Ji-Mr.V1i1.252 
3178 Pengaruh Penggunaan Reward Stiker Pictured terhadap Kemampuan Membaca Puisi Siswa di Sekolah Dasar - Khafita Wahdatul Khoiroh, Syamsul Ghufron, Nafiah, Sri Hartatik DOI: https://doi.org/10.31004/basicedu.v5i5.1324

Wahyono, P., Husamah, H., \& Budi, A. S. (2020). Guru Profesional Di Masa Pandemi Covid-19: Review Implementasi, Tantangan, Dan Solusi Pembelajaran Daring. Jurnal Pendidikan Profesi Guru, 1(1), 5165. Http://Ejournal.Umm.Ac.Id/Index.Php/Jppg/Article/View/12462

Yunitasari, R., \& Hanifah, U. (2020). Pengaruh Pembelajaran Daring Terhadap Minat Belajar Siswa Pada Masa Covid 19. Edukatif: Jurnal Ilmu Pendidikan, 2(3), 232-243. Https://Doi.Org/10.31004/Edukatif.V2i3.142 